\title{
Charitable Donations, Political Connections and Top Executive Stock Ownership:Evidence from Chinese Listed Companies
}

\author{
Ying Shu \\ School of Economics and Management \\ Nanjing University of Science and Technology \\ Nanjing, China
}

\begin{abstract}
Based on resource dependence theory, principalagent theory and institutional theory, a total of 893 samples from 2008 to 2014 were empirical analyzed, this paper studies the relationship between the intensity of charitable donation, political connections, institutional environment and the change of top executive stock ownership in China. Our results indicate that

(1) Charitable donation is positively related to top executive stock ownership. ( 2 ) Charitable donations are positively correlated with top executive stock ownership in companies with political connections. However, in a companies without political connections, the relationship is not significant. (3) The degree of marketization has a significant positive moderating effect on the correlation between charitable donation and top executive stock ownership. However, in companies without political connections, the moderating effect of the degree of marketization on charitable donation and top executive stock ownership is not obvious.
\end{abstract}

Keywords-charitable donations; political connections; top executive stock ownership; institutional environment

\section{INTRODUCTION}

Nowadays, the topic of charitable donation is more and more concerned by the public. However, the attitude of the top executives to charity behavior of listed companies is rarely studied. At the same time, top executives' political connections and Chinese unique institutional environment are also important aspects of top executive stock ownership. The charitable donation of Chinese enterprises not only promotes the development of public utilities, but also alleviates the pressure on the government. Charitable donations narrowed the distance between enterprises and government, and enabled enterprises to obtain government protection, which can be described as a win-win behavior. It can be seen in China that corporate philanthropy is not only the performance of social responsibility, but also has the meaning of building the relationship between government and enterprises. In the China market, unstable policies, non-standard business environment and the changeable institutional environment make political connections and charitable donations become the best way to avoid the risk of enterprises, which further affects the top executive attitude to the prospects of the company and the top executive stock ownership.

\section{LITERATURE REVIEW AND HYPOTHESIS DEVELOPMENT}

\section{A. Charitable Donations and Top Executive Stock Ownership}

There are many factors that influence corporate philanthropy, such as company size, profitability and growth [1.2.3]. Under the influence of many factors, corporate philanthropy will also have multiple effects, such as the impact of the company's top executive stock ownership [4]. Atkinson's study found that the company's stake in CEO was positively correlated with the amount of charitable donations [5]. From the perspective of managers' self-interest hypothesis, the more attention CEO pay to corporate reputation, the larger corporate philanthropy will be. Based on the agency cost theory, study shows that the higher the proportion of top executive stock ownership, the more likely the company is to donate [6].Some scholars have come to different conclusions, such as Li 's study of Listed Companies in China found that the proportion of the largest shareholder stake and corporate charitable donations negatively related [7]. Based on the theory of agency cost, the large shareholders will restrict the company's charitable behavior out of the protection of their own interests. Based on this discussion, we propose Hypothesis 1 as follows.

H1: Charitable donation is positively related to top executive stock ownership.

\section{B. Charitable Donations, Political Connections and Top Executive Stock Ownership}

Corporate charitable donations can bring a lot of benefits, such as tax incentives, political protection and market opportunities [8.9.10], each of them can promote the improvement of the company's operating conditions, which will undoubtedly increase the top executives' expectations for the future of the company. From the principal-agent theory, the separation of the two rights of modern enterprise ownership and management rights, there is a principal-agent relationship between the shareholders and executives, that is, the executive is the agent of the shareholders. If top executives can see the private equity gains in the company's charitable donations, it is bound to increase the proportion of their holdings. 
However, China is still in the economic transition period at present, has not yet established a complete set of mechanisms to separate the government from the market, the government still has a lot of social resources. According to the theory of resource dependence, the resources of listed companies are limited in certain areas. Access to more critical resources from the government has become the main channel to enhance competitiveness, so it is necessary for listed companies to establish a good relationship with the government. Some companies may choose to bribe, but charitable donation is the first choice for most companies, because it is not only in line with the law, but also can establish a good corporate image in the government and the public. Based on this discussion, we propose Hypothesis 1a and Hypothesis $1 \mathrm{~b}$ as follows.

H1a : Charitable donations are positively correlated with top executive stock ownership in companies with political connections.

$\mathrm{H} 1 \mathrm{~b}$ : There is no significant correlation between charitable donation and top executive stock ownership in companies with no political connections.

\section{Charitable Donations, Political Connections, Institutional Environment and Top Executive Stock Ownership}

China has unique institutional environment, such as government intervention, market competition and property rights system, so that Chinese listed companies will face different situations when operate and charitable donation will have different effects. What's more, the effects in politically connected enterprises and enterprises without political connections are different. Studies have shown that the higher the degree of marketization in a region, the more willing the company in the region to donate [11]. Today, people invest in the company, not only concerned about its profitability, but also concerned about its reputation in the community, this reputation is often reflected through charitable donations and other acts of social responsibility. Relative to consumers, shareholders and other groups, executives in the pursuit of the development of the company will also pay attention to the fulfillment of corporate social responsibility.

Gang Fang [12] and Hujie Ma [13] selected degree of marketization, intermediary and legal environment, the relationship between government and market and factor market in four dimensions to measure Chinese system environment, using the panel data study, they found that the performance of institutional environment and corporate social responsibility is positively related. Xiaoqin Zhao [14] found that the degree of marketization is negatively correlated with the number of charitable donations and the size of the company's donation. Yuejun Tang [15] found that Chinese enterprises will charity donate in order to reduce the risk of instability in the institutional environment. Based on the theory of market transition and institutional motivation, the marketization reform is negatively related to corporate philanthropy, and this relationship is more significant in state-owned enterprises. Based on the system theory, Peng Xie [16] examines the positive correlation between the institutional environment and the pressure of the charity donation, if a company in the environment of moral legitimacy and regional isomorphism pressure, the company may have more charitable donation behavior. Therefore, there is no denying that the institutional environment has a moderating effect on charitable donations and top executive stock ownership. Based on this discussion, we propose Hypothesis 2a and Hypothesis $2 \mathrm{~b}$ as follows.

H2a : The degree of marketization has a significant positive moderating effect on the correlation between charitable donation and top executive stock ownership.

$\mathrm{H} 2 \mathrm{~b}$ : In the company without political connections, the degree of marketization is not significantly related to the relationship between charitable donation and executive stock ownership.

\section{RESEARCH DESIGN}

\section{A. Sample Selection and Data Sources}

In this paper, the sample selected Chinese listed companies from 2008 to 2014, excluding the companies whose charitable donations information is not reported or data is not completed, the total number of valid samples is 893. Institutional environment is from "China's marketization index: the relative process of marketization in different regions in 2011", the rest of the data are taken from CSMAR database. The sample distribution in 51 provinces, municipalities and regional ethnic autonomous regions, distributed in 16 industries, the geographical distribution and industry distribution are extensive, provides representative data for the research of institutional environment.

\section{B. Variable Descriptions}

In this paper, we use the broad categories of top executives, including the directors of listed companies, supervisors, general manager, deputy general manager, chief financial officer, secretary of the board of directors and so on.

We use the relative value of charitable donation rather than the absolute value of charitable donations, because the same amount of donations in different sizes of the company has different components, so the absolute amount of charitable donations has less practical significance.

Political connection refers to the top executives of listed companies are currently or have worked in government or military, or they are NPC deputies or CPPCC members. The definition of varities is shown in "Table I". 
TABLE I. DEFINITION OF VARIABLES

\begin{tabular}{|c|c|c|}
\hline Variables & Symbol & Definitions \\
\hline \multicolumn{3}{|l|}{$\begin{array}{l}\text { Dependent } \\
\text { variable: }\end{array}$} \\
\hline $\begin{array}{l}\text { Top executive } \\
\text { shareholding } \\
\text { change }\end{array}$ & Hold & $\begin{array}{l}\text { hold= Current executive shareholding } \\
\text { ratio } \\
\text {-The base executives shareholding ratio }\end{array}$ \\
\hline \multicolumn{3}{|l|}{$\begin{array}{l}\text { Independent } \\
\text { variables: }\end{array}$} \\
\hline $\begin{array}{c}\text { Charitable } \\
\text { donation scale }\end{array}$ & Don & $\begin{array}{l}\text { Donation }=\operatorname{Ln}(\text { Donated Amount } * 100 / \\
\text { Total assets }+1)\end{array}$ \\
\hline $\begin{array}{l}\text { Political } \\
\text { connection }\end{array}$ & $\mathrm{PC}$ & $\begin{array}{l}\text { Executives of listed companies have } \\
\text { political connections, the Political value is } \\
1 \text {, otherwise the Political value is } 0 \text {. }\end{array}$ \\
\hline \multicolumn{3}{|l|}{$\begin{array}{l}\text { Moderating } \\
\text { variable }\end{array}$} \\
\hline $\begin{array}{l}\text { Institutional } \\
\text { environment }\end{array}$ & MKT & $\begin{array}{l}\text { Data from the" Chinese market index: the } \\
\text { relative process of regional market in } \\
2011 \text { Report" }\end{array}$ \\
\hline \multicolumn{3}{|l|}{$\begin{array}{c}\text { Control } \\
\text { variables: }\end{array}$} \\
\hline company size & Size & Size $=\ln$ (Ending total assets) \\
\hline Ownership type & Own & $\begin{array}{l}\text { The state-owned listed company, the } \\
\text { Ownership value is } 1 \text {, otherwise the } \\
\text { Ownership value is } 0 \text {. }\end{array}$ \\
\hline Tobin Q & Q & $\begin{array}{l}\mathrm{Q}=(\text { Market value of equity }+ \text { Net debt } \\
\text { market capitalization) / Total assets }\end{array}$ \\
\hline $\begin{array}{l}\text { Return on total } \\
\text { assets }\end{array}$ & ROA & $\begin{array}{l}\text { ROA }=\text { net profit/ Annual average total } \\
\text { assets } \times 100 \%\end{array}$ \\
\hline $\begin{array}{l}\text { Asset liability } \\
\text { ratio }\end{array}$ & Lev & Lev $=$ Total liabilities $/$ Total assets \\
\hline $\begin{array}{c}\text { Industry } \\
\text { characteristics }\end{array}$ & Industry & $\begin{array}{l}\text { Reference to the SFC industry } \\
\text { classification } 2012 \text { Edition }\end{array}$ \\
\hline Particular year & Year & 2008 to 2014 \\
\hline
\end{tabular}

\section{Research Models}

This paper puts forward the following models by considering the relationship between corporate philanthropy, political association and executive stock ownership:

Hold $=\beta 0+\beta 1$ Don $+\beta 2$ Size $+\beta 3$ Own $+\beta 4 Q+\beta 5$ ROA $+\beta 6$ Lev $+\beta 7$ Industry $+\beta 8$ Year $+\varepsilon$

Hold $=\beta 0+\beta 1$ MKT $+\beta 2$ Don $+\beta 3$ Don* MKT $+\beta 4$ Size $+\beta 5$ Own $+\beta 6$ $\mathrm{Q}+\beta 7 \mathrm{ROA}+\beta 8$ Lev $+\beta 9$ Industry $+\beta 10$ Year $+\varepsilon$ (2)

Where $\beta 0$ is the intercept, $\beta \mathrm{i}$ are the regression coefficients of the test variables and the control variables, respectively, and $\varepsilon$ is the residual error.

\section{EMPIRICAL RESULTS AND ANALYSIS}

\section{A. Descriptive Statistics}

In this paper, the descriptive statistics are mainly shown in "Table II". In "Table II", the dummy variable IFDon indicates whether the listed companies are involved in charitable donations. If the listed company has made charitable donations in the corresponding year, the value of IFDon is 1, otherwise the value is 0 . From the descriptive statistics of variables, we find that in the 893 valid samples, only $42.2 \%$ of the sample has made charitable donations in the corresponding year, less than half of the total samples, so we think that the extent of charity donation of listed companies need to be improved. Don standard deviation is very small, which indicates that the listed companies have considered their own scale in charitable donations. The standard deviation of MKT is the biggest, which shows that the Chinese institutional environment is very different, and it is necessary to consider this index when analyzing the relationship between charitable donation, political association and top executive stock ownership.

\section{TABLE II. DESCRIPTIVE STATISTICS}

\begin{tabular}{|c|l|l|l|l|l|}
\hline & \multicolumn{1}{|c|}{$\mathbf{N}$} & \multicolumn{1}{|c|}{ Min } & \multicolumn{1}{|c|}{ Max } & \multicolumn{1}{|c|}{ Mean } & SD \\
\hline hold & 893 & -0.092 & 0.238 & 0.001 & 0.014 \\
\hline IFDon & 893 & 0.000 & 1.000 & 0.422 & 0.494 \\
\hline Don & 893 & $0.000 \%$ & $95.331 \%$ & $2.074 \%$ & 0.069 \\
\hline QA & 893 & 0.051 & 33.270 & 1.573 & 1.991 \\
\hline ROA & 893 & -0.326 & 0.619 & 0.057 & 0.070 \\
\hline lev & 893 & 0.015 & 1.843 & 0.527 & 0.209 \\
\hline MKT & 893 & 0.000 & 11.800 & 8.393 & 2.246 \\
\hline Size & 893 & 18.265 & 28.413 & 23.083 & 1.329 \\
\hline
\end{tabular}

\section{B. Correlation Analysis}

The Pearson correlation between the variables are shown in "Table III" and "Table IV". We can see that there is a significant positive correlation between Don and Hold, showed that the bigger the proportion of corporate charitable donations to the total assets of the company is, the more obviously the top executives increase the proportion of shareholding. At the same time, there is a significant positive correlation between MKT and Hold, indicating that the higher the market indexes in a region, the more positive the proportion of executive stock ownership. The correlation coefficients between the variables are almost less than 0.5 , indicating that there is no multicollinearity in the independent variables, dependent variables, control variables and control variables. Of course, Pearson correlation analysis is only a preliminary investigation of the relationship between variables, we also need to further test the regression model.

TABLE III. PEARSON CORRELATION MATRIX(1)

\begin{tabular}{|c|l|l|l|l|}
\hline & \multicolumn{1}{|c|}{$\mathbf{1}$} & \multicolumn{1}{|c|}{$\mathbf{2}$} & \multicolumn{1}{c|}{$\mathbf{3}$} & \multicolumn{1}{c|}{$\mathbf{4}$} \\
\hline hold & 1 & & & \\
\hline PC & -0.011 & 1 & & \\
\hline Don & $0.068^{*}$ & 0.014 & 1 & \\
\hline Size & -0.014 & $0.076^{*}$ & $-0.088^{* *}$ & 1 \\
\hline Own & $-0.116^{* *}$ & $-0.103^{* *}$ & -0.044 & $0.143^{* *}$ \\
\hline QA & 0.004 & 0.026 & $0.127^{* *}$ & $-0.437^{* *}$ \\
\hline ROA & 0.046 & $0.100^{* *}$ & $0.237^{* *}$ & $-0.155^{* *}$ \\
\hline lev & -0.034 & -0.012 & $-0.121^{* *}$ & $0.465^{* *}$ \\
\hline MKT & $0.089^{* *}$ & -0.008 & -0.021 & $0.115^{* *}$ \\
\hline
\end{tabular}

Note: *,**,***, 0.1, 0.05, 0.01 in level (bilateral) significant correlation.

TABLE IV. PEARSON CORRELATION MATRIX(2)

\begin{tabular}{|c|l|l|l|l|l|}
\hline & \multicolumn{1}{|c|}{$\mathbf{5}$} & \multicolumn{1}{|c|}{$\mathbf{6}$} & \multicolumn{1}{|c|}{$\mathbf{7}$} & \multicolumn{1}{|c|}{$\mathbf{8}$} & $\mathbf{9}$ \\
\hline hold & & & & & \\
\hline PC & & & & & \\
\hline Don & & & & & \\
\hline Size & & & & & \\
\hline Own & 1 & & & & \\
\hline QA & $-0.137^{* *}$ & 1 & & & \\
\hline ROA & $-0.163^{* *}$ & 0.428 & 1 & & \\
\hline lev & $0.152^{* *}$ & -0.501 & -0.413 & 1 & 1 \\
\hline MKT & $-0.158^{* *}$ & $-.036^{* *}$ & 0.121 & -0.017 & 1 \\
\hline
\end{tabular}

Note: *,**,***, 0.1, 0.05, 0.01 in level (bilateral) significant correlation. 


\section{Regression Results}

1) Regression analysis of charitable donations and executive stock ownership.

The regression results are shown in "Table V". Column (1) showed that the regression coefficient of Donation and Hold was significant at the level of 0.01 (bilateral), indicating that the intensity of charitable donation of listed companies is positively related to the change of top executive stock ownership, That is, the bigger the proportion of charitable donations to total assets is, the greater the increase in the size of executive stock ownership, so the Hypothesis 1 is verified.

TABLE V. Charitable DONATIONS, POLITICAL CONNECTIONS AND EXECUTIVE STOCK OWNERSHIP IN INSTITUTIONAL ENVIRONMENT.

\begin{tabular}{|c|c|c|c|c|c|}
\hline & ALL & $\mathrm{PC}=1$ & $P C=1$ & $\mathbf{P C}=0$ & $\mathbf{P C}=0$ \\
\hline & (1) & (2) & (3) & (4) & $(5)$ \\
\hline \multirow[t]{2}{*}{ Don } & $\begin{array}{l}1.952 \\
* * *\end{array}$ & $\begin{array}{l}2.183 \\
* * *\end{array}$ & $\begin{array}{l}1.982 \\
* * *\end{array}$ & 1.665 & 1.463 \\
\hline & $(2.96)$ & (2.83) & (3.42) & $(0.85)$ & $(0.91)$ \\
\hline \multirow[t]{2}{*}{ MKT } & & & 0.019 & & 0.015 \\
\hline & & & $(0.93)$ & & $(1.19)$ \\
\hline \multirow[t]{2}{*}{$\begin{array}{l}\text { Don x } \\
\text { MKT } \\
\end{array}$} & & & $\begin{array}{l}0.111 \\
* * *\end{array}$ & & 0.049 \\
\hline & & & (2.86) & & $(0.61)$ \\
\hline \multirow[t]{2}{*}{ size } & $\begin{array}{l}0.022 \\
* * *\end{array}$ & $\begin{array}{l}0.020 \\
* * *\end{array}$ & $\begin{array}{l}0.026 \\
* * *\end{array}$ & $\begin{array}{l}0.028 \\
* *\end{array}$ & $\begin{array}{l}0.024 \\
* *\end{array}$ \\
\hline & $(3.85)$ & $(3.47)$ & $(3.59)$ & (1.84) & (1.67) \\
\hline \multirow[t]{2}{*}{ Own } & $\begin{array}{l}-0.144 \\
* *\end{array}$ & $\begin{array}{l}-0.099 \\
* *\end{array}$ & $\begin{array}{l}-0.058 \\
* *\end{array}$ & $\begin{array}{l}-0.184 \\
*\end{array}$ & $\begin{array}{l}-0.164 \\
*\end{array}$ \\
\hline & $(-2.18)$ & $(-2.11)$ & $(-2.02)$ & $(-1.82)$ & $(-1.75)$ \\
\hline \multirow[t]{2}{*}{ QA } & $\begin{array}{l}-0.011 \\
* * *\end{array}$ & $\begin{array}{l}-0.013 \\
* * *\end{array}$ & $\begin{array}{l}-0.003 \\
* * *\end{array}$ & $\begin{array}{l}-0.005 \\
* *\end{array}$ & $\begin{array}{l}0.000 \\
* *\end{array}$ \\
\hline & $(-3.55)$ & $(-3.30)$ & $(-3.07)$ & $(-2.42)$ & $(2.03)$ \\
\hline \multirow[t]{2}{*}{ lev } & $\begin{array}{l}-0.008 \\
* * *\end{array}$ & $\begin{array}{l}-0.039 \\
* * *\end{array}$ & $\begin{array}{l}-0.050 \\
* * *\end{array}$ & $\begin{array}{l}0.058 \\
* *\end{array}$ & $\begin{array}{l}0.115 \\
* *\end{array}$ \\
\hline & $(-3.08)$ & $(-3.22)$ & $(-3.26)$ & $(2.28)$ & $(2.06)$ \\
\hline \multirow[t]{2}{*}{ _cons } & $\begin{array}{l}-0.317 \\
* * *\end{array}$ & $\begin{array}{l}-0.310 \\
* * *\end{array}$ & $\begin{array}{l}-0.622 \\
* * *\end{array}$ & $\begin{array}{l}-0.480 \\
* *\end{array}$ & $\begin{array}{l}-0.552 \\
* *\end{array}$ \\
\hline & $(-4.60)$ & $(-4.35)$ & $(-4.74)$ & $(-2.36)$ & $(-2.23)$ \\
\hline $\mathbf{N}$ & 893 & 383 & 383 & 510 & 510 \\
\hline r2_a & 0.022 & -0.036 & -0.014 & 0.061 & 0.066 \\
\hline $\mathbf{F}$ & 0.890 & 0.475 & 0.586 & 0.823 & 0.790 \\
\hline
\end{tabular}

2) Regression analysis of charitable donations, political connections and executive stock ownership.

The regression results are shown in column (2) (4) in table IV. Column (2) shows the regression results of charitable donations to executive stock ownership in listed companies with political connections. Column (4) shows the regression results of charitable donations to top executive stock ownership in listed companies without political connections. By comparison, we find that in listed companies with political connections, the executives' shareholding is positively related to charitable donations in strength, and in the 0.01 level (bilateral) significant correlations, the correlation coefficient is 2.183, this result is consistent with $\mathrm{H} 1 \mathrm{a}$ and $\mathrm{H} 1 \mathrm{~b}$.

3) Regression analysis of charitable donations, political connections and executive stock ownership in institutional environment.

The regression results are shown in column (3) and column (5) of table IV. By comparison, in listed companies with political connections, institutional environment plays a regulatory role in strengthening between philanthropy strength and executive ownership changes; the regression coefficient was 0.111 at the 0.01 level (bilateral) significant correlations. Indicates that in listed companies with political connection, higher market index, greater proportion of charitable donations to the total assets, company's future expectations will be better ,the changes in the shareholding ratio will be more obvious, and the change is increasing the proportion of ownership. This result is consistent with $\mathrm{H} 2 \mathrm{a}$ and $\mathrm{H} 2 \mathrm{~b}$.

\section{CONCLUSION}

Most of the literatures just studied the factors that influence the corporate philanthropy. In this paper, we take corporate philanthropy as a starting point, studying its effect on listed company top executives shareholding changes. We find another factor that affects the change of top executive shareholding is whether the listed companies have political connections. Not only that, we also take the regulatory role of the institutional environment into account. The main conclusions of this paper are as follows:

First, the charitable donation of listed companies is positively related to the change of top executive stock ownership. Companies with larger scale and better profitability, corporate charitable donation is greater, because after a large number of charitable donations, they have enough ability to resist possible cash flow risk and the possibility of the company financial risk is relatively small, or even if there is a problem in the short term, they also have the ability to solve it in time. In this case, the top executives' confidence of the company will be greatly improved; they will have very good expectations for the company's future business conditions, so they will increase the shareholding ratio of the company.

Second, charitable donations and top executive ownership are positively related in listed companies with political connections. There is no significant correlation between charitable donation and top executive stock ownership of listed companies without political connections. Compared with no political connections of listed companies, listed companies with political connections make charitable donations can be known by the government immediately, which can strengthen the friendly relations between the company and the government, increase access to limited social resources and opportunities. The listed companies without political connections not only lack of the way to be known by the government after charity donation, but also have no need for leaders to show their political attitudes through charitable donations. Therefore, even if the listed companies have a charitable donation, there will not have a significant positive impact to the future of the company, such as direct economic benefits or access to indirect government protection. In view of this, top executives' attitude of listed companies will not greatly changed even though the company make charitable donation, so the proportion of shares will not change with changing in charitable donations.

Third, the degree of marketization has a significant positive moderating effect on the correlation between charitable donation and top executive stock ownership. In the company without political connections, the degree of marketization is not significantly related to the relationship between charitable 
donation and top executive stock ownership. It is necessary to consider the special institutional environment in China when study the charitable donation, institutional environment differences will lead to the society having different attitudes towards corporate charitable donation, even the same attitude will reflect different degrees. When the institutional environment of a region is better, the listed companies in the region are more willing to charitable donations, and top executive will have the better expectations for the future, so the proportion of shareholding changes will be greater. This is because the good system environment and resources often bring better opportunities to enterprises, such as natural resources, social resources, legal protection and the degree of government intervention; it can attract more investors and potential consumers than in the areas of poor institutional environment. A good institutional environment for executives refers to a sense of security, so that executives believe that corporate charitable donations will not affect the normal operation of the company. At the same time, the listed companies with political connections will further strengthen the relationship between the government and the enterprises in the process of charitable donations, and obtain more government protection and resources.

\section{REFERENCES}

[1] Campbell J L. Why would corporations behave in socially responsible ways? An institutional theory of corporate social responsibility [J]. Academy of Management Review, 2007,32(3):946-967.

[2] Julian S D, Ofori Dankwa J C. Financial resource availability and corporate social responsibility expenditures in a sub - Saharan economy: The institutional difference hypothesis[J]. Strategic Management Journal, 2013,34(11):1314-1330.

[3] Clarkson M B E. A stakeholder framework for analyzing and evaluating corporate social performance [J]. Academy of Management Review, 1995, 20(1):92-117.

[4] Atkinson L, Galaskiewicz J. Stock Ownership and Company Contributions to Charity[J]. Administrative Science Quarterly, 1988, 33(1):82-100.

[5] Cheng B, Ioannou I, Serafeim G. Corporate social responsibility and access to finance[J]. Strategic Management Journal, 2014,35(1):1-23.

[6] Ming Jia, Zhe Zhang. The political connections of top executives affecting corporate philanthropy? [J]. management world, 2010 (4): 99113.

[7] Eccles R G, Ioannou I, Serafeim G. The impact of corporate sustainability on organizational processes and performance[J]. Management Science, 2014,60(11):2835-2857.

[8] Li W, Zhang R. Corporate social responsibility, ownership structure, and political interference: Evidence from china[J]. Journal of Business Ethics, 2010,96(4):631-645.

[9] Yingchun Zhu. The incentive effect of tax policy on corporate philanthropy in China: An Empirical Study Based on the data of listed companies of A shares in China in the year 2007 [J]. finance and economics, 2010 (1): 36-42.。 political protection

[10] Jing Huang. Study on the relationship between corporate philanthropy and tax policy [D]. Zhejiang University, 2011

[11] Tianli Feng, Runtian Jing. House system environment and private entrepreneurs political connections will empirical research on [J]. management world, 2009 (8): 81-91.Gang Fang,

[12] Xiaolu Wang, Guangrong Ma. Contribution of China's marketization process to economic growth [J]. economic research, 2011 (9): 4-16

[13] Hujie Ma, Tailing Xu, Kuirang Shi. Social capital, institutional environment and corporate social responsibility -- Based on the $2009 \sim$
2011 A shares panel data of the listed companies [J]. Journal of Capital University of Economics and Business, 2013, 15 (3): 85-94.

[14] Xiaoqin Zhao, Difang Wang. Provincial Influence factors of Chinese enterprise disaster relief donations -- an empirical study of "5 - 12" earthquake donations of mainland enterprises $[\mathrm{J}]$. management review, 2012, 24 (2): 171-176

[15] Yuejun Tang, Jingjing Zuo, Huidong Li. Study on the influence mechanism of institutional environment change on corporate philanthropy [J]. economic research, 2014 (2): 61-73

[16] Peng Xie, Chunlin Liu. Research on moral legitimacy, regional isomorphism and corporate philanthropy behavior: evidence from listed companies in China [J]. Nanjing Social Sciences, 2015 (3): 50-58. 